\title{
Cytogenetic and identification of the nucleolus organizer region in Heliconia bihai (L.) L. ${ }^{1}$
}

\author{
Heloisa Rocha do Nascimento ${ }^{2}$, Ricardo Gallo , Isane Vera Karsburg $^{4}$, Ademilso Sampaio Oliveira \\ http://dx.doi.org/10.1590/0034-737X201461040002
}

\begin{abstract}
The genus Heliconia is not much studied and the number of existing species in this genus is still uncertain. It is known that this number relies between 150 to 250 species. In Brazil, about 40 species are native and known by many different names. The objective of this paper was to characterize morphometrically and to identify the NOR (active nucleolus organizer regions) by Ag-NOR banding of chromosomes of Heliconia bihai (L) L. Root meristems were submitted to blocking treatment in an amiprofos-methyl (APM) solution, fixed in methanol-acetic acid solution for 24 hours, at least. The meristems were washed in distilled water and submitted to enzymatic digestion with pectinase enzyme. The slides were prepared by dissociation of the root meristem, dried in the air and also on hot plate at $50^{\circ} \mathrm{C}$. Subsequently, some slides were submitted to 5\% Giemsa stain for karyotype construction and to a solution of silver nitrate $\left(\mathrm{AgNO}_{3}\right) 50 \%$ for Ag-NOR banding. The species $\mathrm{H}$. bihai has $2 \mathrm{n}=22$ chromosomes, 4 pairs of submetacentric chromosomes and 7 pairs of metacentric chromosomes, and graded medium to short (3.96 to $0.67 \mu \mathrm{M}$ ), with the presence of active NOR in pairs 1 and 2 and interphase cells with 2 nucleoli. These are the features of a diploid species.
\end{abstract}

Key words: $\mathrm{AgNO}_{3}$, amiprofos-methyl, karyotype, heliconeaceae, morphometry.

\section{RESUMO}

\section{Citogenética e identificação da região organizadora nucleolar em Heliconia bihai (L.) L.}

O gênero Heliconia é pouco estudado e o número de espécies existentes é incerto, compreendendo entre 150 e 250 espécies. No Brasil, cerca de 40 espécies ocorrem naturalmente e são conhecidas por vários nomes. Esta pesquisa teve como objetivo a caracterização morfométrica e a identificação da NOR (regiões organizadoras de nucléolos ativos), pelo bandeamento Ag-NOR dos cromossomos de Heliconia bihai (L.) L. Foram utilizados meristemas radiculares, submetidos ao tratamento de bloqueio em solução de amiprofos-metil (APM), fixados em solução de (metanol-ácido acético), por, no mínimo, 24 horas. Os meristemas foram lavados em água destilada e submetidos à digestão enzimática, com a enzima pectinase. As lâminas foram confeccionadas por dissociação do meristema radicular, secadas ao ar e, em seguida, em placa aquecedora, a $50^{\circ} \mathrm{C}$. Subsequentemente, algumas lâminas foram submetidas ao corante Giemsa 5\%, para confecção do cariótipo, e à solução de nitrato de prata $\left(\mathrm{AgNO}_{3}\right) 50 \%$, para o bandeamento Ag-NOR. A espécie $H$. bihai apresenta $2 \mathrm{n}=22$ cromossomos, quatro pares de cromossomos submetacêntricos e sete pares de cromossomos metacêntricos, classificados de médio a curtos ( 3.96 à $0.67 \mu \mathrm{m})$, com presença de NOR ativa nos pares $(1 \mathrm{e} 2)$ e células interfásicas com dois nucléolos. Estas características são de espécie diploide.

Palavras-chave: $\mathrm{AgNO}_{3}$, amiprofos-metil, cariótipo, heliconeaceae, morfometria.

\footnotetext{
Recebido para publicação em 27/03/2013 e aprovado em 05/12/2013.

${ }^{1}$ Extracted from graduation study by the first author.

${ }^{2}$ Agronomist. Universidade do Estado de Mato Grosso, Campus Alta Floresta, Avenida Perimetral Rogério Silva, s/n, Flamboyant, Caixa Postal 324, 78580-000, Alta Floresta, Mato Grosso, Brazil. helornasc@gmail.com (corresponding author).

${ }^{3}$ Forest engineer. Departamento de Ciência Florestal, Universidade Federal de Viçosa, Campus Viçosa, Avenida Peter Henry Rolfs, s/n, 36570-000, Viçosa, Minas Gerais, Brazil. gallo.florestal@yahoo.com.br

${ }^{4}$ Biologist, Doctor in Science. Departamento de Ciências Biológicas, Universidade do Estado de Mato Grosso, Campus Alta Floresta, Avenida Perimetral Rogério Silva, s/n, Bairro Flamboyant, Caixa Postal 324, 78580-000, Alta Floresta, Mato Grosso, Brazil. isane9@yahoo.com.br

${ }_{5}^{5}$ Geographer, Master in Science. Departamento de Agronomia, Universidade do Estado de Mato Grosso, Campus Alta Floresta, Avenida Perimetral Rogério Silva, s/n, Flamboyant, Caixa Postal 324, 78580-000, Alta Floresta, Mato Grosso, Brazil. adesampa@bol.com.br
} 


\section{INTRODUCTION}

Sole representative of Heliconeaceae family, the genus Heliconia (L.) (Cronquist, 1981) presents 176 species of neotropical occurrence, and six species in the Pacific Islands, totaling 182 (Castro et al., 2007). According to Andersson (1989) and Kress (1990), in Brazil, the genus Heliconia is represented by 21 species in the Amazon basin, and 20 species in the Atlantic Forest, and some of these species may be endemic in these regions.

According to Castro (1995), Castro \& Graziano (1997), Torres et al. (2005), in Brazil, the heliconias are also known as banana-of-garden, little banana-of-garden, guara's beak, false-bird-of-paradise, parrot-beack or paquivera. According to Andersson (1989) and Torres et al. (2005), the heliconias occur in shady places such as forests and riparian forests, or in places with no shadow at all such as edge of forests, clearings and roadside.

Heliconia bihai (L.) L. presents erect inflorescence with distical orientation bracts and varied coloration, being one of the most cultivated species in Brazil (Santana et al., 2010). According to Kress \& Berry (1991), in addition to the natural hybrids, the species displays around 15 cultivars. Castro et al. (2007) report that there are about 40 commercial cultivars of $\mathrm{H}$. bihai.

The Heliconia genus includes a great diversity of species, varieties, hybrids and cultivars of ornamental and commercial interest. Some species of this family and its varieties and hybrids are grown for producing cut flowers for their beauty, color and intensity of the inflorescences. The tuber rhizome of some species can be eaten if roasted or cooked, such as in Heliconia hirsuta (L.f.), known as "Isira" or "Bijao". Heliconia bihai is common in the Amazon Rainforest and widely used in the preparation of regional dishes, using the leaves for food packaging (Berry \& Kress, 1991; Castro et al., 2007).

The identification of species and cultivars is based on morphological characteristics and on the color of the flowers and inflorescences. However, natural variations between individuals and between populations have caused much disagreement among collectors, farmers and researchers (Berry \& Kress, 1991). Although the genus has been being the subject of taxonomic revisions, it has been poorly studied, with confusion and uncertainty about the number of species and the relationship between them (Marouelli, 2009).

Thus, karyotypic information, from a simple count to detailed molecular studies, is an important aid in taxonomic identification (Stace, 2000). Karyotype analyzes are a useful procedure for the differentiation of close taxonomic categories, particularly for those where the phenotypic characteristics are insufficient for reliable sorting into distinct taxa, as well as, in many cases, clarifying the cytological and genetic foundations of variability within a family (Martinez, 1976).

Besides the taxonomic significance, other authors have emphasized that the cytogenetic information can also help in studies on evolution, genomics and breeding of plant species (Galasso et al., 2001; Doyle et al. 2004; Biondo et al., 2005; Figueroa \& Bass, 2010).

Several techniques have been improved, with the advances in preparations that allow the improvement of classical methodologies (Sybenga, 1992; Viccini \& Carvalho, 2000; Figueroa \& Bass, 2010). One of the advances related with the preparation of these studies is the use of antimitotic agents, or inhibitors such as amiprofos-methyl (APM) herbicides, 8-hidroxyquilonein, trifluralin and oryzalin that block cell cycles in specific phases of mitosis (Sumner, 1990; Singh, 1993; Rossi et al., 2008).

The blocking agents, such as APM, are essential for studying the chromosomes, for preventing the formation of the spindle and accumulating sufficient number of metaphase for a proper morphometric analysis, enabling the classification and identification of homologous pairs (Singh, 1993; Araújo, 2008; Rossi et al., 2008; Karsburg et al., 2009). Using APM also results in elongated chromosomes, with adequate compression for cytogenetic analysis (Planchais et al., 2000).

Besides the use of mitotic agents, the use of fixative solutions such as methanol: acetic acid allows to obtain good quality preparations (Ghosh \& Paweletz, 1993), characterized in stretched, straight chromosomes. The use of fixative solutions also prevents the action of endonucleases, which permits detailed characterization of the karyotype of the species under study (Sumner 1990; Sybenga, 1992), as well as increases basophilia of the chromosomes, facilitating their coloration (Sharma \& Sharma, 1999 cited by Araújo, 2008). Moreover, the techniques of enzymatic maceration, cell dissociation and air drying enable obtaining slides with prometaphase and metaphase chromosomes, spread with no overlaps and in the same focal plane (Carvalho, 1995; Araújo, 2008; Rossi et al., 2008; Karsburg et al., 2009).

Another cytogenetic technique that can be applied to plant species is Ag-NOR banding. This technique identifies the active nuclear organizing regions (NOR's), consisting of one or more chromosome pairs, showing rDNA genes responsible for the formation of different types of rRNA that form the nucleolus and ribosomes (Miller et al., 1976; Howell \& Black, 1980; Sumner, 1990; Guerra, 1988; Sumner, 2003).

The objectives of this work were the morphometric characterization and identification of NOR by Ag-NOR banding of chromosomes of Heliconia bihai, aiming at enhancing the cytogenetic knowledge of the species and genus at matter. 


\section{MATERIALAND METHODS}

Mitotic analyzes were performed in the laboratory of Cytogenetics and Plant Tissue Culture at the Mato Grosso State University - Campus II in Alta Floresta.

To obtain the karyotype, root meristems of Heliconia bihai (L.) L. species were used. The plants were collected in the municipality of Alta Floresta, in Comunidade Central, located at the northern end of the state of Mato Grosso, at $10^{\circ} 27^{\prime} 56^{\prime \prime} \mathrm{S}$ and $56^{\circ} 09^{\prime} 01^{\prime \prime} \mathrm{W}$, at an average altitude of 284 meters, in 9,310.27 $\mathrm{km}^{2}$ in area (Miranda \& Amorim, 2001).

Root meristems were obtained by exposing the rhizomes in water at $30^{\circ} \mathrm{C}$, which was changed daily until meristems reached 1.0 to $1.5 \mathrm{~cm}$ in length. After development, they were submitted to blocking treatment, which consisted of permanence of meristems in amiprofosmethyl (APM) Sigma ${ }^{\circledR}$ herbicide solution at a concentration of $3 \mu \mathrm{mol} \mathrm{L}{ }^{-1}$ at $4^{\circ} \mathrm{C}$ for 16 hours. This process allowed the accumulation of a maximum number of cells in metaphase. Then the roots were rinsed in distilled water to remove excess of the herbicide, and fixed in methanol-acetic acid solution at a ratio of $3: 1$ in the same temperature conditions.

The root meristems were removed from the fixative solution and washed in distilled water for five minutes. The roots were removed from the water and transferred to Eppendorf ${ }^{\circledR}$ tubes with pressure cap containing enzyme Pectinase $\operatorname{Sigma}^{\circledR}(\mathrm{PA})$ at a concentration of $3 \mu \mathrm{mol} \mathrm{L}{ }^{-1}$, remaining at $35^{\circ} \mathrm{C}$ in a water bath for two hours. Once enzymatic reaction was over, the material was rinsed in distilled water again, performing three changes at intervals of 15 minutes, and fixed in methanol acetic acid solution (3:1) for at least 24 hours at $4^{\circ} \mathrm{C}$.

For the preparation of slides, root meristems were dissociated using a scalpel and a fixing solution. The slides were air dried in fast movings and dried on hot plates at $50^{\circ} \mathrm{C}$, according to the methodology described by Carvalho \& Saraiva (1993). The slides were stained with Giemsa $5 \%, \mathrm{pH} 7.0$, for three minutes, washed in distilled water and dried.

Regarding Ag-NOR banding, the slides were aged for 20 days, according to Funaki et al. (1975), and a solution of silver nitrate $\left(\mathrm{AgNO}_{3}\right)$ with $50 \%$ of saturation was dropped on the slides. Then, the slides were covered with glass slides and exposed in a humid dark chamber at $35^{\circ} \mathrm{C}$ for 18 hours. After the incubation period, the glass slides were removed by water jets and the slides were washed in running water for 2 minutes and in distilled water for 1 minute

The target methases were photographed by a binocular photon (Leica ${ }^{\circledR}$ ICC 50), coupled to a computer with LAZ EZ VI. 7.0 software, and analyzed using the public domain software Image/J version 1.46r (2012), developed by the National Institute of Health (INS, Bethesda, MD, USA), together with the Java programming language, version 1.6.0 (Abramoff et al., 2004), both of which can be obtained through the internet at http:// rsb.info.nih.gov/ij/, for software ImageJ and http:// www.java.com/, for Java language

Length of the arms of the chromosomes was converted from pixels to micrometer scale. The cariogram was organized in decreasing order of size, from the measurement of chromosome arms. The ratio amongs the arms ( $r$ ) was determined according to the criterion of morphological classification of chromosomes, described by Guerra (1986).

\section{RESULTS AND DISCUSSION}

The standardization of the protocol used in the study was crucial for the supply and characterization of metaphase chromosomes, allowing the assembly of the karyotype of $\mathrm{H}$. bihai. The use of the inhibitor agent, amiprofos-methyl (APM), was effective in the accumulation of metaphases to perform the analysis of the morphology, size and number of chromosomes. The action of the pectinase enzyme, at $35^{\circ} \mathrm{C}$ for $2 \mathrm{~h}$, was effective in eliminating the cell wall without damaging the structure of chromatin, so a proper staining with Giemsa at $5 \%$ and $\mathrm{pH} 7.0$ was achieved. Similar results, using the inhibitor agent APM and Giemsa staining at 5\% were obtained with Coffea arabica (L.) (Clarindo \& Carvalho, 2008), Solanum esculentum (L.) (Karsburg et al., 2009) and Carica papaya (L.) (Araújo et al., 2010).

Moreover, the dissociation processes by cells from digested root meristems, together with the air-drying technique were efficient because it was possible to obtain well spread chromosomas on the focus plane without cytoplasmic background, overlapping or structural deformation, facilitating observation. Identical results, regarded to the quality of mitotic metaphase, were obtained with Solanum esculentum (Karsburg et al., 2009), Capsicum annuum (L.) (Abreu et al., 2008), Jatropha curcas (L.) (Carvalho et al., 2008), Psychotria ipecacuanha [(Brot.) Stoves] (Rossi et al., 2008) and Carica papaya L. (Araújo et al., 2010). Thus, this method provides more appropriate preparations of chromosomes compared to those generated by the crushing method (Carvalho \& Saraiva, 1993).

New tools for observation and analysis of chromosomes of plants are becoming more accessible to characterize the chromosome morphology (Bauchan \& Hossain, 2001; Barret \& Carvalho, 2003; Abramoff et al., 2004). The binocular photon microscope (Leica ${ }^{\circledR}$ ICC 50), coupled to the computer and the use of LAZ EZ VI. 7.0 software were important tools for capturing good quality 
images of chromossomes of cells in metaphase. The same success was obtained with Jatropha curcas species (Mergonar et al., 2010), Theobroma speciosum (Willd. Ex Spreng) (Gallo \& Karsburg, 2010), Catasetum longifolium (C. Rich. ex Kunth) (Gomes et al ., 2011) and $+\&$ Cattleya violácea [(Kunth) Rolfe] x “type" ô\&Cattleya granulosa (Lindl.) (Silva et al., 2011). However, the use of public domain program Image/J was essential for image analysis, contributing to the measurements of the chromosomes, analysis of homologous pairs and assembly of the karyotype. Similar results were obtained with Oryza (L.) spp. (Miyabayashi et al., 2007), Brachiaria (L.) spp. (Akiyama et al., 2010), Antirrhinum rothmaleri [(P.Silva) Amich, Bernardos \& García-Barriuso] (Garcia-Barriuso et al., 2011) and Macleaya cordata (syn. Bocconia cordata Willd) (Samatadze et al., 2012).

The morphometric analysis showed that $H$. bihai has $2 n=22$ chromosomes (Figure 1). The same number of chromosomes was also reported in the study by Oliveira (2010) in the species H. stricta (Huber), H. psittacorum (L. f.), H. rostrata (Ruiz \& Pavan), H. hirsuta (lf). According to Kaemwong \& Eksomtramage (1998), the species $H$. metallica (Planch. \& Linden ex Hook.), H. Wagner cv. Arco-íris (Peters) also presented $2 \mathrm{n}=22$ chromosomes, while $H$. rostrata, $H$. caribaea (Lam.) Cv. Purpurea, $H$. latispatha (Benth.) Cv. Vermelho-Amarelo, H. psittacorum (Lf) x H. marginata [(Griggs) Pittier] H. psittacorum cv. Rubra, $H$. psittacorum cv. Periquito, $H$. psittacorum cv. Lady Di, H. psittacorum cv. Sassy, H. psittacorum, $H$. stricta cv. Jamaicano-anão, $H$. psittacorum x $H$. spathocircinata (Arist.) have $2 \mathrm{n}=24$ chromosomes and the species $H$. densiflora (B. Verl.) Cv. Fogo Flash has $2 \mathrm{n}$ $=36$. However, Andersson (2008), obtained 2n $=24$ chromosomes in 31 species of Heliconia, representing almost all the morphological spectrum of the genus. Thus, it is evident that the genus presents a wide divergence, ranging from $2 n=22$ to $2 n=36$ chromosomes

The methodology used for morphometric and morphological analysis of the chromosomes of $\mathrm{H}$. bihai allowed to observe the occurrence of four pairs of submetacentric chromosomes $(6,8,9$ and 10) and seven pairs of metacentric chromosomes (1, 2, 3, 4, 5, 7 and 11) (Table 1).

Oliveira (2010), when evaluating $H$. stricta species, found nine pairs of submetacentric and two pairs of metacentric chromosomes; however, H. psittacorum species presented four submetacentric pairs, six metacentric pairs and one acrocentric pair while in the

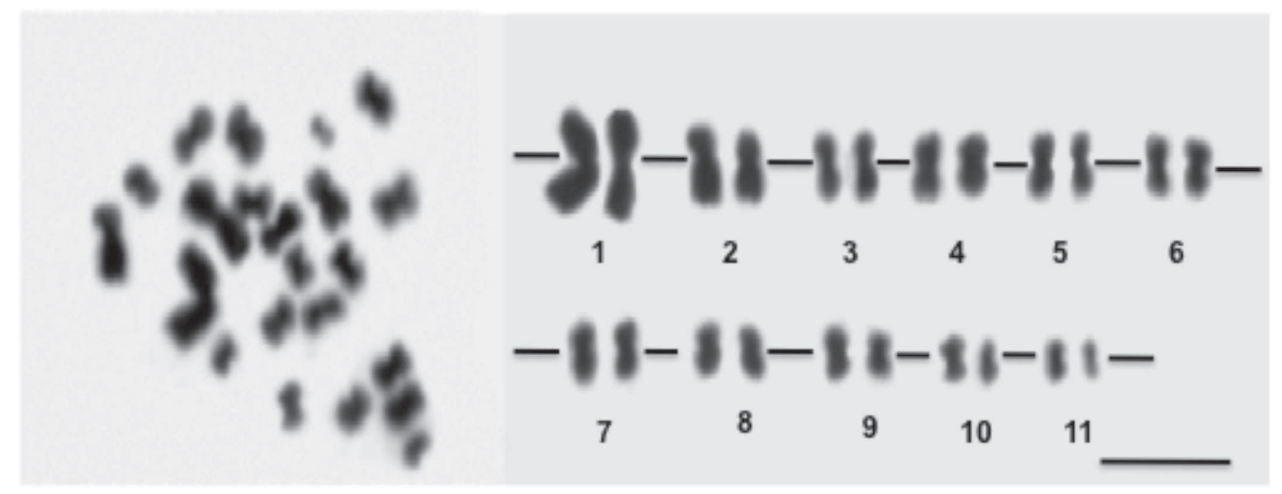

Figure 1. Metaphase and karyotype of $H$. bihai presenting $2 \mathrm{n}=22$ chromosomes stained with Giemsa $5 \%$. Bar $=5 \mu \mathrm{m}$.

Table 1. Measurements and morphology of the chromosomes of $H$. bihai according to the position of the centromere.

\begin{tabular}{lcccccc}
\hline \multirow{2}{*}{ Chromossome } & $\begin{array}{c}\text { Total length } \\
(\boldsymbol{\mu})\end{array}$ & \multicolumn{2}{c}{ Arm $(\boldsymbol{\mu m})$} & $\begin{array}{c}\text { Ratio between } \\
\text { arms }\end{array}$ & $\begin{array}{c}\text { Centromere } \\
\text { index }(\mathbf{C I})\end{array}$ & $\begin{array}{c}\text { Chromossome } \\
\text { morphology }\end{array}$ \\
\cline { 3 - 4 } & 3.96 & 1.87 & 2.09 & 1.12 & 47.22 & $\mathrm{M}$ \\
2 & 2.39 & 1.08 & 1.31 & 1.21 & 45.19 & $\mathrm{M}$ \\
3 & 2.05 & 0.88 & 1.17 & 1.33 & 42.93 & $\mathrm{M}$ \\
4 & 1.94 & 0.90 & 1.04 & 1.16 & 46.39 & $\mathrm{M}$ \\
5 & 1.65 & 0.82 & 0.83 & 1.01 & 49.70 & $\mathrm{M}$ \\
6 & 1.60 & 0.71 & 0.89 & 1.25 & 36.51 & $\mathrm{SM}$ \\
7 & 1.57 & 0.72 & 0.86 & 1.19 & 45.86 & $\mathrm{M}$ \\
8 & 1.26 & 0.46 & 0.80 & 1.74 & 36.50 & $\mathrm{SM}$ \\
9 & 1.26 & 0.46 & 0.80 & 1.74 & 36.50 & $\mathrm{SM}$ \\
10 & 1.04 & 0.31 & 0.73 & 2.35 & 29.81 & $\mathrm{SM}$ \\
11 & 0.67 & 0.30 & 0.37 & 1.23 & 44.78 & $\mathrm{M}$ \\
\hline
\end{tabular}

Subtitle: Ratio between arms = Long arm /Short arm; CI = Short arm/Total length x 100; M = metacentric; SM = submetacentric. 

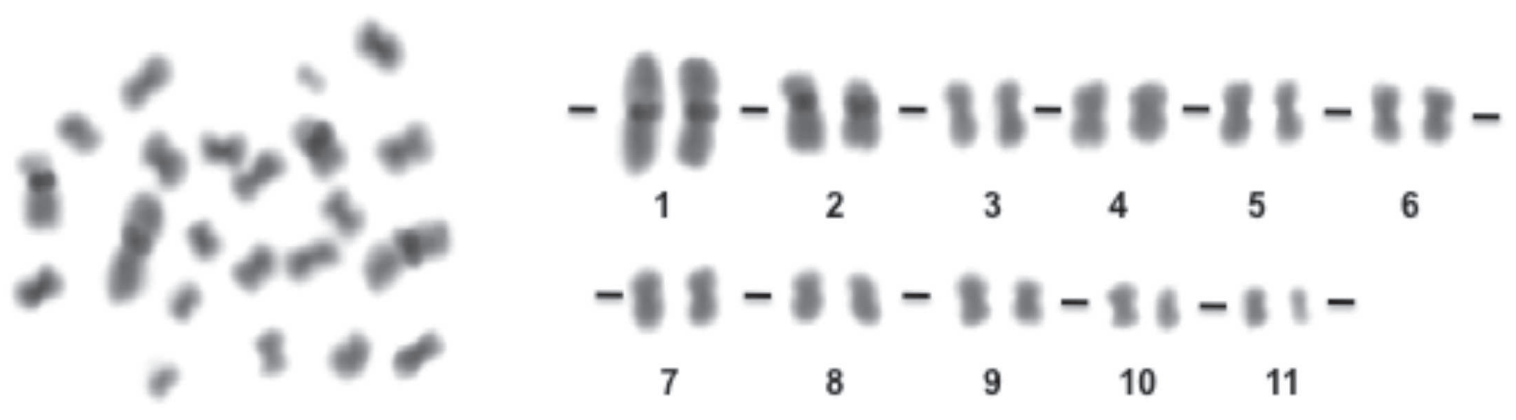

Figure 2. Chromossomes of root meristems of $H$. bihai, pretreated with APM $3 \mu \mathrm{mol} \mathrm{L}{ }^{-1}$ for 16 hours at $4{ }^{\circ} \mathrm{C}$. Chromosomes were stained with $\mathrm{AgNO}_{3}$ for 18 hours at $35^{\circ} \mathrm{C}$ with the presence of active NOR on chromosome pairs (1 and 2). Bar $=5 \mu \mathrm{m}$.

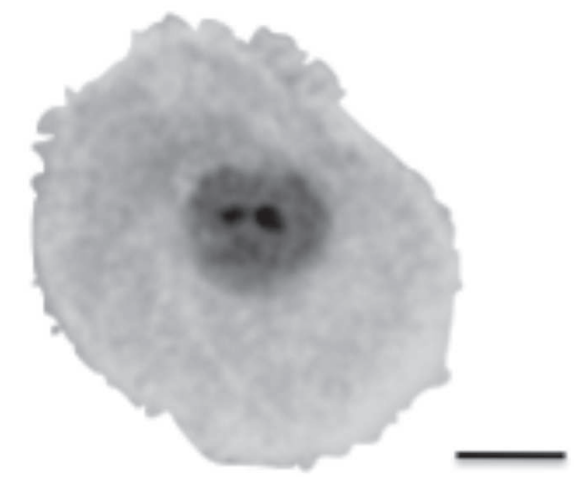

Figure 3. Cell in interfase stained with $\mathrm{AgNO}_{3}$ for 18 hours at $35^{\circ} \mathrm{C}$ presence of two nucleoli. $\mathrm{Bar}=5 \mu \mathrm{m}$.

species $H$. rostrata, five submetacentric pairs, five metacentric pairs and one acrocentric pair were found. Therefore, one can say that the genus presents chromosome morphology varying among submetacentric, acrocentric and metacentric.

According to John (1980), the length of a chromosome is regarded a constant. Distinguishing by their length, chromosomes can be classified arbitrarily as long ( $>10$ ì $\mathrm{m})$, medium $(4-8 \mu \mathrm{m})$ or short $(<2 \mu \mathrm{m})$. Thus, the species studied displayed medium to short chromosomes (from 3.96 to $0.67 \mu \mathrm{m}$ ), and most of them were short. The results obtained with Heliconia were consistent with those of other studies. Oliveira (2010), with H. stricta and H. hirsute, found that the chromosomes ranged from medium to short (1.04 to $4.13 \mu \mathrm{m}$ and from 0.28 to $4.36 \mu \mathrm{m}$ ). The chromosomes of $H$. psittacorum and $H$. rostrata were classified only as short, displaying sizes from 1.19 to 3.29 $\mu \mathrm{m}$ and from 1.72 to $3.04 \mu \mathrm{m}$, respectively. Andersson (2008), evaluationg 31 species of the genus Heliconeaceae, found that all chromosomes of 31 species of the genus in matter, had total length between 0.7 and 1.7 ì m, being classified only as short.

Regarding the nucleolus organizer regions (NOR), the active region of $H$. bihai is located at the middle portion of the centromere, on the chromosome pairs (1 and 2) (Figure 2). During mitosis, the active NORs are those where rDNAs are associated with proteins that associate themselves with silver (Roussel , 1996; Morais-Cecílio et al, 2000; Besendorfer et al, 2002; Brasileiro- Vidal et al., 2003; Almeida \& Carvalho, 2004; Neves et al., 2005; Clarindo \& Carvalho, 2006). The presence of the active NOR on pairs (1 and 2) indicates, according to Mergonar et al. (2010), that these chromosomal regions have chromosome domains around which nucleoli at the end of mitosis are arranged, when the rDNA transcription is initiated.

During interphase, two nucleoli were identified per $H$. bihai cell (Figure 3). According to Mergonar et al. (2010), the number of NORs and nucleoli found can be regarded as features of diploid. Generally, polyploidy show less visible NORs in sets of chromosome than the expected by the sum of diploid genomes (Vaughan et al., 1993; Aarestrup et al., 2008). Reducing the number of NORs and nucleoli during polyploidy, might also be associated with nucleolar suppression (Vaughan et al., 1993).

\section{CONCLUSIONS}

The methodologies used in this work were efficient in conducting the study and achievement of satisfactory results. The $H$. bihai species has $2 \mathrm{n}=22$ chromosomes; out of these, four pairs are submetacentric and seven pairs are metacentric, and classified as medium to short (3.96 to $0.67 \mu \mathrm{m})$. The active NOR present in pairs (1 and 2 ) and interphase cells with the presence of two nucleoli can be considered as characteristics of a diploid species.

\section{REFERENCES}

Aarestrup JR, Karam D \& Fernandes GW (2008) Chromosome number and cytogenetics of Euphorbia heterophylla L. Genetics and Molecular Research, 7:217-222.

Abramoff MD, Magalhães PJ \& RAM SJ (2004) Image processing with Image J. Biophotonics International, 7:36-42. 
Abreu IS de, Carvalho CR \& Clarindo WR (2008) Chromosomal DNA content of sweet pepper determined by association of cytogenetic and cytometric tools. Plant Cell Reports, 7:12271233 .

Almeida PM \& Carvalho CR (2004) NOR-associated heterochromatin of pepper chromosomes stained with acridine orange. Caryologia, 2:177-181.

Andersson L (1989) An evolutionary scenario for the genus Heliconia. Tropical forest: botanical dynamics, speciation and diversity, 1:173-184.

Andersson L (2008) The chromosome number of Heliconia (Musaceae). Nordic Journal of Botany, 2:191-193.

Akiyama Y, Yamada-Akiyama H \& Ebina M (2010) Morphological diversity of chromosomes bearing ribosomal DNA loci in Brachiaria species. Grassland Science, 4:217-223.

Araújo FS (2008) Estudos citogenéticos e citrométricos em mamoeiro (Carica papaya L.). Dissertação de Mestrado. Universidade Federal de Viçosa, Viçosa. 58p.

Araújo FS, Carvalho CR \& Clarindo WR (2010) Genome size, base composition and karyotype of Carica papaya L. Nucleus, 53:25-31

Barret SD \& Carvalho CR (2003) A software tool to straighten curved chromosome images. Chromosome Research, 11:83-88.

Bauchan GR \& Hossain MA (2001) A computerized image analysis system to characterize small plant chromosomes. Microscopy Analysis, 48:5-7.

Berry F \& Kress WJ (1991) Heliconia: an identification guide. Washington, Smithsonian Institution Press. 334p.

Besendorfer V, Samard•ija M, Zoldoš V, Šoliæ ME \& Papeš E (2002) Chromosomal organization of ribosomal genes and NORassociated heterochromatin, and NOR activity in some populations of Allium commutatum Guss. (Alliaceae). Botanical Journal of the Linnean Society, 139:99-108.

Biondo E, Miotto STS \& Schifino-Wittmann MT (2005) Citogenética de espécies arbóreas da subfamília Caesalpinioideae - Leguminosae do sul do Brasil. Ciência Florestal, 15:241-248.

Brasileiro-Vidal AC, Cuadrado A, Brammer SP, Zanatta ACA, Prestes AM, Moraes-Fernandes MIB \& Guerra M (2003) Chromosome characterization in Thinopyrum ponticum (Triticeae, Poaceae) using in situ hybridization with different DNA sequences. Genetics and Molecular Biology, 26:505-510.

Carvalho CR (1995) Desenvolvimento de tecnologia citogenética em milho (Zea mays L.). Tese de Doutorado. Universidade Federal de Viçosa, Viçosa. 127p.

Carvalho CR, Clarindo WR, Praça MM, Araújo FS \& Carels N (2008) Genome size, base composition and karyotype of Jatropha curcas L., an important biofuel plant. Plant Science, 174:613-617

Carvalho CR \& Saraiva LS (1993) An air drying technique for maize chromosomes without enzymatic maceration. Biotechnic e Histochemistry, 68:142-145.

Castro CEF (1995) Cultivo de Helicônias para exportação. Brasília, FRUPEX. 42p.

Castro CEF de \& Graziano TT (1997) Espécies do gênero Heliconia (Heliconiaceae) no Brasil. Revista Brasileira de Horticultura Ornamental, 3:15-28.

Castro CEF de, May A \& Gonçalves C (2007) Atualização da nomenclatura de espécies do gênero Heliconia (Heliconiaceae). Revista Brasileira de Horticultura Ornamental, 13:38-62.

Clarindo WR \& Carvalho CR (2006) A high quality chromosome preparation from cell suspension aggregates culture of Coffea canephora. Cytologia, 71:243-249.
Clarindo WR \& Carvalho CR (2008) First Coffea arabica karyogram showing that this speciesis a true allotetraploid. Plant Systematics and Evolution, 274:237-241.

Cronquist A (1981) An integrated system of classification of flowering plants. New York, Columbia University Press. 1262p.

Doyle JJ, Doyle JL Rauscher JT \& Brown AHD (2004) Evolution of the perennial soybean polyploidy complex (Glycine subgenus Glycine): a study of contrasts. Biological Journal of the Linnean Society, 82:583-897.

Figueroa DM \& Bass HW (2010) A historical andmodern perspective on plant cytogenetics. Briefings in functional genomics, 9:95-102.

Funaki K, Matsui S \& Sasaki M (1975) Location of nucleolar organizers in animal and plant chromosomes by means of an improved N-banding technique. Chromosoma, 49:357-370.

Galasso I, Schmidt T \& Pignone D (2001) Identification of Lens culinaris ssp. culinaris chromosomes by physical mapping of repetitive DNA sequences. Chromosome Research, 9:199-209.

Garcia-Barriuso M, Nabais C, Crespí AL, Fernández-Castrllano C, Bernardos S \& Amich F (2011) Morphology and karyology of Antirrhinum rothmaleri comb. \& stat. nov. (Plantaginaceae), a plant endemic to the NW Iberian Peninsula. Annales Botanici Fennici, 48:409-421.

Ghosh S \& Paweletz N (1993) Mitosis: dissociability of its events. International Review of Cytology, 144:217-257.

Gomes CM, Karsburg IV, Lauton DS, Santos AC \& Bilieri CE (2011) Morfometria Cromossomica de Catasetum longifolium C. Rich. ex Kunth. In: $4^{\circ}$ Congresso de iniciação científica, Cáceres. Anais, Universidade do Estado de Mato Grosso, CD-ROM.

Guerra MS (1986) Reviewing the chromosome nomenclature of levan et al. Revista Brasileira de Genética, 9:741-743.

Guerra M (1988) Introdução à citogenética geral. São Paulo, Guanabara. 135p.

Howell WM \& Black BA (1980) Controlled silver-straining of nucleolus organizer regions with a protective colloidal developed: a 1-step method. Experientia, 36:1014-1015.

John B (1980) Citogenética de populações. São Paulo, Pedagógica e Universitária Ltda. 84p.

Kaemwong S \& Eksomtramage L (1998) Chromosome numbers of genus Heliconia. Songklanakarin Journal of Science and Technology, 20:489-495.

Karsburg IV, Carvalho CR \& Clarindo WR (2009) Identification of chromosomal deficiency by flow cytometry and cytogenetics in mutant tomato (Solanum lycopersicum, Solanaceae) plants. Australian Journal of Botany, 57:444-449.

Kress I (1990) The diversity and distribution of Heliconia (Heliconiaceae) in Brazil. Acta Botanica Brasilica, 4:159-167.

Martinez AP (1976) Procedimiento para facilitar el estudio de cromosomas en materiales vegetales difíciles. Cuadernos Biological, 5:53-60.

Marouelli LP (2009) Análise filogenética de acessos do gênero Heliconia L. (Heliconiaceae) utilizando marcadores moleculares. Dissertação de Mestrado. Universidade de Brasília, Brasília. 88p.

Miller DA, Dev VG, Tantravahi R \& Miller OJ (1976) Supression of human nucleolus organizer activity in mouse-human somatic hybrid cells. Experimental Cell Research, 101:235-243.

Miranda L \& Amorim L (2001) Mato Grosso - Atlas Geográfico. Cuiabá, Editora Entrelinhas. 40p.

Miyabayashi T, Nonomura KI, Morishima H \& Kurata N (2007) Genome size of twenty wild species of Oryza determined by flow cytometric and chromosome analyses. Breeding Science, 57:73-78. 
Morais-Cecílio L, Delgado M, Jones RN \& Viegas W (2000) Modification of wheat rDNA loci by rye B chromosomes: a chromatin organization model. Chromosome Research, 8:341351

Neves N, Delgado M, Silva M, Caperta A \& Morais-Cecílio L \& Viegas W (2005) Ribosomal DNA heterochromatin in plants. Cytogenetics and Genome Research, 109:104-111.

Oliveira ANB de (2010) Caracterização cromossômica de quatro espécies do gênero Helicônia. Trabalho de Conclusão de Curso. Universidade do Estado de Mato Grosso, Alta Floresta. 16p.

Planchais S, Glab N, Inzé D \& Bergounioux C (2000) Chemical inhbitors: a tool for plant cell cycle studies. FEBBS Letters, 476:78-83.

Rossi AAB, Clarindo WR, Carvalho CR \& Oliveira LO de (2008) Karyotype and nuclear DNA content of Psychotria ipecacuanha: a medicinal species. Cytologia, 73:53-60.

Roussel P, André C, Comai L \& Hernandez-Verdun D (1996) The rDNA transcription machinery is assembled during mitosis in active NORs and absent in inactive NORs. The Journal of Cell Biology, 123:235-246.

Samatadze TE, Zelenin AV, Suslina SN, Amosova AV, Popov KV, Zagumennikova, TN, Tsytsylin AN, Bykov VA \& Muravenko OV (2012) Comparative cytogenetic study of the forms of Macleaya cordata (Willd.) R. Br. from different localities. Russian Journal of Genetics, 48:63-69.

Santana CVM de, Loges V \& Leite AV de L (2010) Biologia reprodutiva e análise da formação de híbridos em Heliconia bihai (L.) L. In: $10^{\mathrm{a}}$ Jornada de ensino, pesquisa e extensão (JEPEX), Recife. Anais, Universidade Federal Rural de Pernambuco. CD-ROM.
Silva GM da, Gallo R, Sacoman NN, Karsburg IV \& Silva ML da (2011) Micropropagação e caracterização cromossômica do "híbrido" Cattleya violácea "tipo" x Cattleya granulosa (Orchidaceae). In: $2^{\text {a }}$ BIOTA, Tangará da Serra. Anais, UFMT. p. $1-6$.

Singh RJ (1993) Plant cytogenetics. Urbana, University of Illinois. $391 \mathrm{p}$.

Stace CA (2000) Cytology and cytogenetics as a fundamental taxonomic resource for the 20 st and 21 st centuries. Taxon, 49:451-476.

Sumner AT (1990) Chromosome banding. London, Unwin Hyman. $434 \mathrm{p}$.

Sumner AT (2003) Chromosomes: Organization and function. Malden, Blackwell. 286p.

Sybenga J (1992) Cytogenetics in plant breeding: Monographs on theorical and applied genetics. $17^{\mathrm{a}} \mathrm{ed}$. 469p.

Torres AC, Duval FG, Ribeiro DG \& Santos M do DM dos S (2005) Produção de mudas de Helicônia rostrata livres de doenças via cultura de embriões. Brasília, EMBRAPA Hortaliças. 12p. (Boletim de Pesquisa e Desenvolvimento, 6).

Vaughan HE, Jamilena M, Rejon RC, Parker JS \& Garrido-Ramos MA (1993) Loss of nucleolar-organizer regions during polyploidy evolution in Scilla autumnalis. Heredity, 71:574-580.

Viccini LF \& Carvalho CR (2000) Maize chromosome 6 deficiency identified by image analysis. Cytologia, 65:71-73. 